\title{
画像解析に基づく七里御浜井田海岸の汀線変化特性に関する研究

\author{
Study on Mechanism of Shoreline Change in Shichiri-mihama Ida Beach Using \\ Web Camera Images
}

\author{
ブーテイランフーン ${ }^{1} \cdot$ 水谷法美 $^{2}$
}

\author{
VU Thi Lan Huong and Norimi MIZUTANI
}

\begin{abstract}
Image analysis using Web camera can be very useful tool to clarify the mechanics of beach deformation because it allows time domain analysis of shoreline changes. The purpose of the present study is to extract shoreline from the video images using image processing and investigate the relationship between shoreline change and waves. New method to detect shoreline in images has been proposed and it has been demonstrated to detect shoreline more stable than the exiting CCD model. Results reveal that the shoreline tends to forward if the significant wave height is ranged between $1 \mathrm{~m}$ and $2 \mathrm{~m}$, whereas it tends to retreat if the significant wave height is larger than $3 \mathrm{~m}$. Furthermore, the image analysis reveals that presence of artificial reefs reduces the retreat of shoreline during storm.
\end{abstract}

\section{1. はじめに}

三重県南部に位置する七里御浜は鬼ヶ城に隣接する木 本港から熊野川河口部に隣接する鵜殿港に延びる延長約 $20 \mathrm{~km}$ におよぶ礫浜海岸である。七里御浜では, 高度経済 成長期以降, 熊野川におけるダムの建設や土砂採取など による海岸への土砂供給量の減少等によって海岸侵食が 顕在化するようになった。そそのた, 特に侵食が厳しい 七里御浜井田地区海岸 (以下, 井田海岸) では人工リー フの設置や養浜など様々な侵食対策がこれまでに行われ てきた。例えば，梶ヶ鼻の北約 $1 \mathrm{~km} の$ 範囲では, 昭和 57 年から昭和 63 年までに消波ブロックが設置されたが, 現 状では多くのブロックは沈下しており (写真-1参照), その機能は十分果たせなくなっている. また, 鵜殿港の 北に隣接する海岸では, 平成 5 年に人エリーフが 2 基設 置され, さらに, 平成 6 年 9 月の台風 26 号による堤防被 災の後, 災害事業として6基の人工リーフが設置された。

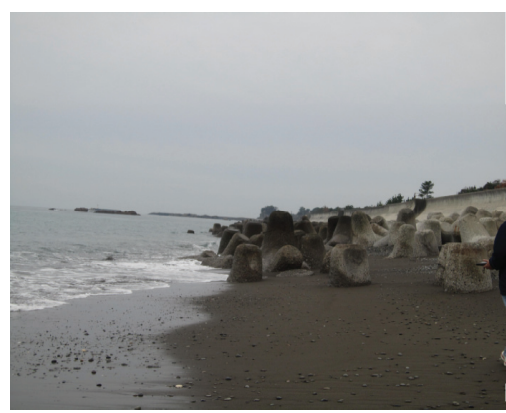

写真-1 2011/11/28の消波ブロックの様子

$\begin{array}{lll}1 \text { 学生会員 } & \text { 修(工) } & \text { 名古屋大学大学院工学研究科 } \\ 2 \text { フェロー } & \text { 工博 } & \begin{array}{l}\text { 名古屋大学教授 大学院工学研究科社会 } \\ \text { 基盤工学専攻 }\end{array}\end{array}$

その後の人工リーフの増設により, 井田海岸にはこれま でに14基の人工リーフが設置されている.

一方, 人工リーフ設置以降の汀線変化についてはいく つか検討例はあるものの, 十分に検討されているとは言 い難いのが現状であり, 今後の有効な海岸侵食対策を検 討する上で, 人工リーフ背後を含め, 長期間にわたる汀 線変化の特性を把握しておくことが重要である. 七里御 浜海岸は波浪エネルギーが高い海岸域で, 年間の汀線変 化も大きい. しかし従来の現地調査や数值計算（宇多ら, 1992 ; 山本ら, 1999 ; 水谷ら, 2003）は, その観測の 時間間隔も長く, 汀線の時間変化を連続的に観察するこ とが困難であった。 そこで本研究では, 井田海岸にWeb カメラを設置し, 海岸線を連続的に撮影した画像にもと づき, 汀線の変化を入射波浪と関連づけて考究すること で, 汀線変化の特性とその機構を検討することを目的と する.

\section{2. 画像解析}

汀線変化の機構を解明するには汀線の経時的な変化を 外力である波浪と関連づけて観測することが望ましく, そのためには, Webカメラを使った画像解析は有効な手 法の一つである. この際, 画像から汀線を検出する手法 が必要である。

本研究では，これまで多くの砂浜で利用された CCD 法 (鈴木ら，2008）に加え, 新たな手法を提案し, 礫浜へ の応用性を検討した。具体的には，まず井田海岸のWeb カメラシステムによるRGB画像を入力データとし, CCD 法の適用性を検討した。 その結果, 雨天など天候の悪い 条件で撮影された画像に対する検出の安定性に改善の余 地が認められたため, このような場合の画像の特徴を考 慮し, 新たな画像解析方法を提案した. 

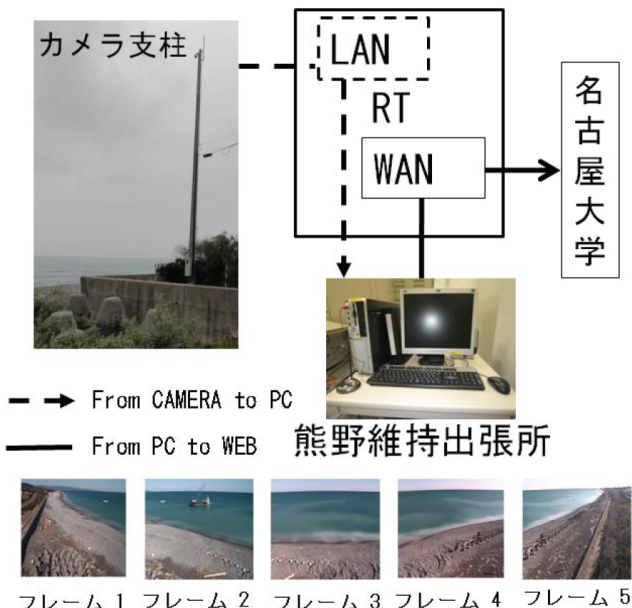

図-1 Webカメラシステムの概要

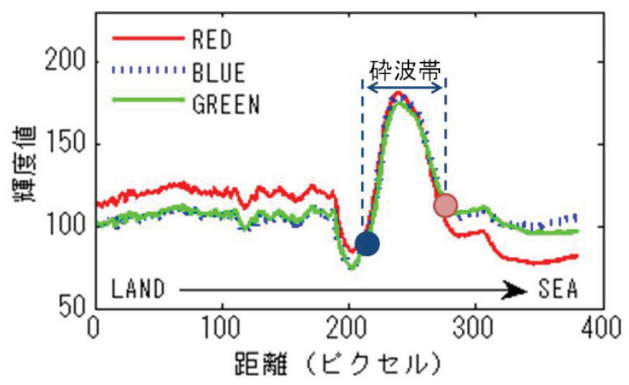

砕波帯最初点 汀線=砕波帯最初点 $* \mathrm{~K}$

図-2 CCD 手法の概要

(1) 七里御浜海岸のWeb カメラシステムと画像解析

Web カメラを, 井田海岸の護岸背後の保安林端部に $20 \mathrm{~m}$ の複合柱を設置し，その最上部に取り付けたＷeb カメラで撮影された画像は，専用光ケーブルで国土交通 省紀勢国道事務所熊野維持出張所に設置したPCに取り 込まれている，画像は，解析の対象としている海岸を 5 つのフレームで撮影している。すなわち，毎日 6:00から 18:00まで，1 フレーム毎に10分間を割り当て，そのうち の 5 分間にわたり画像を 1 秒間隔で記録し，これを一つ のデータセットとしている (図-1参照)。これを5つのフ レームで繰り返し，最後の10分は作業用時間としている. さらに画像を撮影しない夜間にそれぞれのデータセット 毎の平均画像を計算し, これを本研究の解析に使用した。 なお，熊野維持出張所内の PCから名古屋大学へのデー 夕転送は，民間のインターネットを介してリモートで入 手している.

\section{（2）CCD法の適用性}

$\mathrm{CCD}$ 法は海面と海浜の色に対して赤と青の明度が異な ることを利用して汀線を取り出している。図-2は砂浜か ら海域における色の構成の岸沖方向変化を示したもので

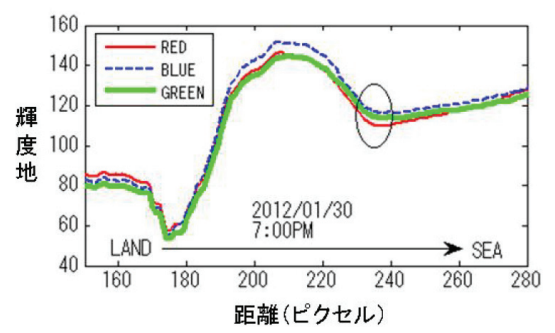

図-3＼cjkstart雨天時における海浜から海面までの色調変化
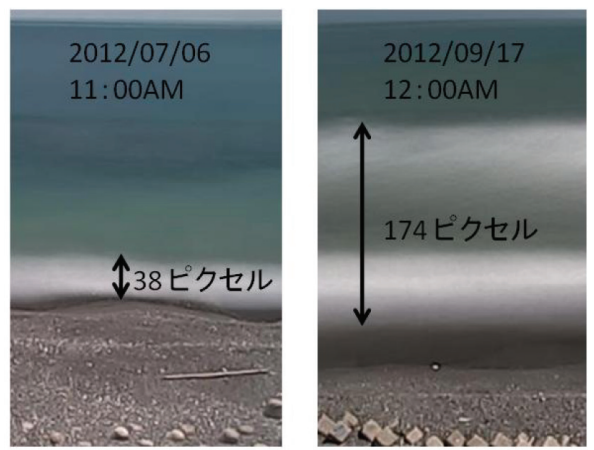

図-4 砕波帯の幅の変化

ある，同図より，海側に進むほど青と赤の輝度の差が大 きくなることがわかる．砕波帯では，波が崩れて白が卓 越することからすべての色調がほぼ同様に高くなるが， $\mathrm{CCD}$ 法ではこの砕波帯の位置と経験的な砕波帯幅を利用 して汀線を推測する。すなわち，K值と呼ばれる経験的 な值を砕波帯幅にかけることで汀線位置を求める．本手 法を七里御浜井田地区海岸に適用した結果，同海岸では $\mathrm{K}=0.81$ とすることで比較的良好に汀線を検出できること が判明した。

しかし，図-3に示すように，雨天時では海浜の赤と海 面の青の違いは明瞭ではなくなるため，砕波帯の位置を 見出すのが困難であり，正しく汀線を抽出することは非 常に困難となる問題が確認された。これは显天時でも共 通の課題である。

礫浜である七里御浜では, 礫浜の浸透性や砂浜斜面上 でエネルギー消散効果が高いこと（李ら，2009），また， 現地の入射波と地形の関係などで，砕波がほぼ汀線付近 まで生じている，一方，図-4に例示するように，低気圧 や台風などの高波浪時には沖の方から広く砕波が生じて おり，このような条件を包含するような海岸固有の $\mathrm{K}$ 值 を見つけることは困難である。ささらに七里御浜は東に面 した海岸であることから，早朝の太陽高度が低い時間带 でのCCD法による汀線の検出も困難であることも判明し た．そこで，本研究では，これらの要因に影響されにく い汀線の検出法について検討を行った. 


\section{（3）新しい画像解析方法の提案}

本研究では, 砕波帯ではなく, 浜の色調の変化そのも のに着目して汀線を検出することとした．図-5に示すよ うに，硗波带の岸側では，陸地から海に近づくほど赤の 輝度值が減少する. 特に汀線近傍で赤の輝度值が急に下 がる.この傾向は図示した条件以外にも共通の特性とし て確認された．そこで，この輝度值の変化に着目し，汀 線の検出を試みた結果が図-6の青のプロットで示した線 である．図-6には CCD 法による検出結果も比較のため赤 で示してある．図-6 (a) は軎天時の例であるが，この場 合，砕波にともなって白く映った範囲が海面全体的に広 がっているため，砕波帯との関係で汀線を検出すること ができなかった例である。しかし，海浜と海面には明確

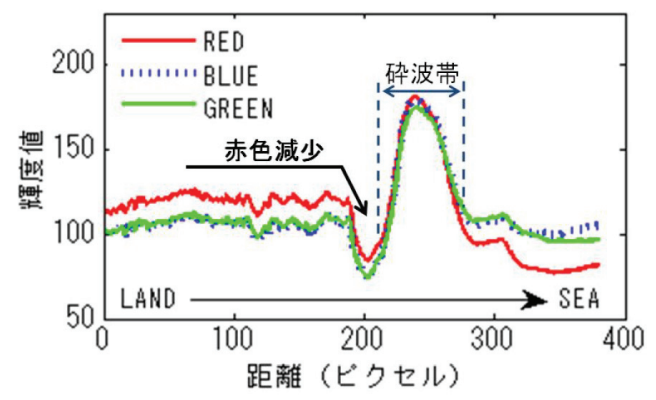

図-5新たな手法の原理

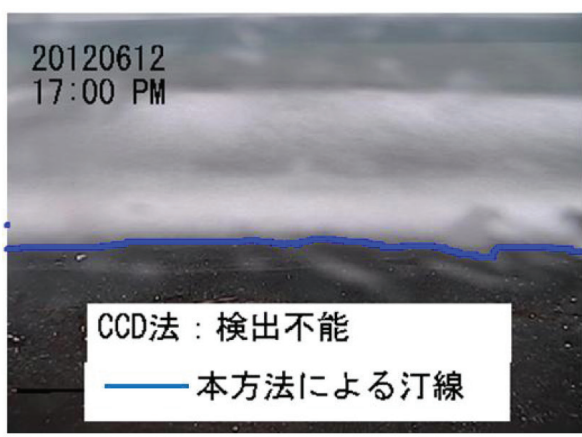

(a) 量天時の例

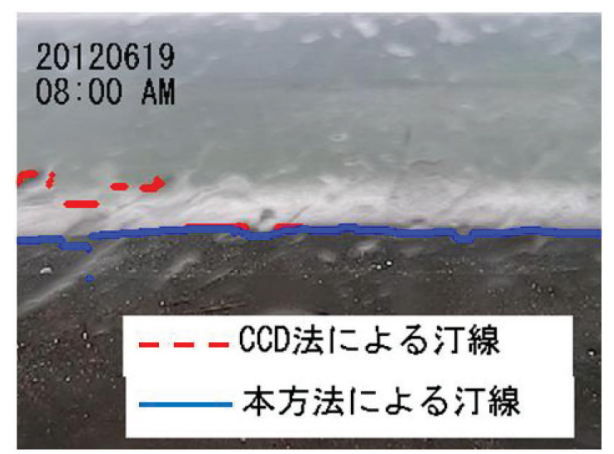

(b) 雨天時の例

図-6 新たな手法と $\mathrm{CCD}$ 手法の比較
な色調の差異があり, 汀線近傍で赤の輝度值の変化は明 瞭に確認でき，本手法により汀線を安定して検出が可能 であった。

図-6 (b) は雨天時の例である. カメラのハウジングに 付着した水滴が白く映るため, 哗波帯との識別が困難に なり，砕波帯幅が局所的に大きく変化するため，固定の K值を使った CCD 法では安定して汀線を検出することは 困難であった。しかし，図-6 (a) と同様に，輝度值の空 間変化そのものを利用した本手法を利用すると，より安 定的に汀線を検出することが可能となった。したがって, 本手法により，CCD法に比べて安定した汀線の検出が可 能となったといえる。な扔, 本手法であってもハウジン グに付着した水滴は画像の輝度值に影響を与えることか らその影響は無視できない。この点については今後も対 応を検討する必要がある。

\section{3. 汀線変化の特性}

上述した手法により検出した汀線の変動特性を，入射 波浪と関連づけて検討する。な打新方法で抽出した汀線 は波の最高到達点である。井田海岸では, 三重県によっ てHFレーダーを使った面的な波浪観測が行われている. したがって, 汀線変化と入射波浪の関係を経時的に解析 することが可能である. 本研究では, 三重県から提供い ただいた波浪観測結果と関連づけた解析を行うこととし た。ただし，HFレーダーの波浪観測に関して，特に 2012 年で久測が頻繁に確認されたため, 七里御浜に比較 的近いナウファス波浪データ (尾熟) も使用することと した。尾熟の波浪デー夕は2012年から提供されている. 以下にその結果について述べる。 なお，すべての汀線位 置は平面直角座標で示す。

（1）七里御浜の波浪要件

図-7にHFレーダー波浪デー夕と尾熟波浪デー夕を示 す．図-7（a）から分かるように，井田海岸には主にSE， ESE方向からの波が卓越していることが確認できる。す なわち, 井田海岸の法線より南からの入射が卓越してお り，したがって北向きの漂砂が卓越することが推察され る. 入射波高を $1 \mathrm{~m}, 1 \sim 2 \mathrm{~m}, 2 \mathrm{~m}$ 以上の 3 つに分けると その割合はそれぞれ約 $35 \%$ ，約 40\%，約 15\%となってい る。また入射波の周期は， $8 \mathrm{~s}$ 以下が約 $40 \% ， 8 \mathrm{~s} \sim 10 \mathrm{~s}$ が 約 $40 \% ， 10$ 以上が約 $20 \%$ を占める. 尾鷲の波浪デー夕 に着目すると，沖で計測されていることから入射方向が 南に広がっているものの, SE, ESE方向が卓越している 傾向は井田海岸と共通である。そこで2012年の波浪に関 しては, HFレーダーの波浪デー夕に欠陥が多いため本研 究では尾熟の波浪デー夕を利用することとした.

(2) 汀線変化

ここでは 2012 年 06 月 1 日から 2012年 12 月 31 日までの 


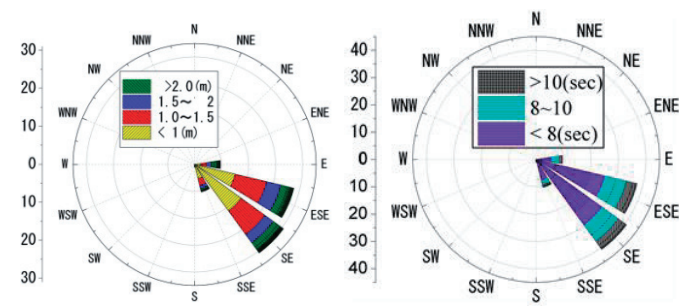

(a) HF レーダーによる入射波特性（井田海岸，2011 年)

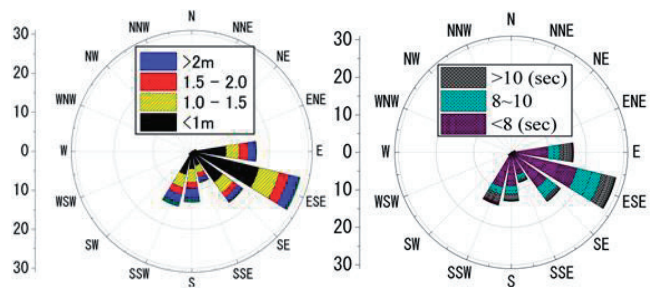

（b）ナウファス (尾熟) による波浪特性（尾鷲，2012 年）

図-7 七里御浜の波浪特性

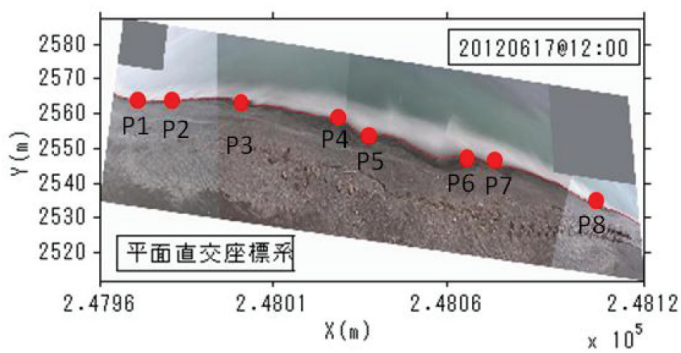

図-8 検討対象区域

汀線変化を, 図-8に示す P1〜 P8の 8 点の汀線位置を使っ て汀線の移動と波浪変化の関係を検討する.

なお，P1，P2，P3は人工リーフの設置区間の北側に位 置する地点で前面海域には構造物は設置されていない. これに対し，P4〜P8 は前面海域に人エリーフが設置さ れた地点になる。 また，図-8に示すように，5つのフレ ームの画像は，座標変換を行って平面画像に修正し，さ らに一枚の連続した画像にして解析を行っている.

\section{a）波浪と汀線変化の関係}

井田海岸では6月から7月にかけて汀線が前進する傾 向がある（水谷ら，2003）。図-9に示すように，この期 間の入射波の波高はほぼ $1 \sim 2 \mathrm{~m}$ のものが卓越している. また，波高が $1 \mathrm{~m}$ 前後の場合，汀線の変化は比較的小さ い傾向が認められた。一方，波高が3mを超える場合に は，一時的に汀線は後退することが多いことも確認され た。一時的に後退した汀線は，その後大きな波が来襲し なければ，ほぼ1週間程度で元の位置に回復するようで ある．8月から 10 月の間では，前半に 1 度 $4 \mathrm{~m}$ を超える波 が来襲し，その後 $1 \mathrm{~m}$ 程度の波がほとんどである。この
Signif icant Wave Height

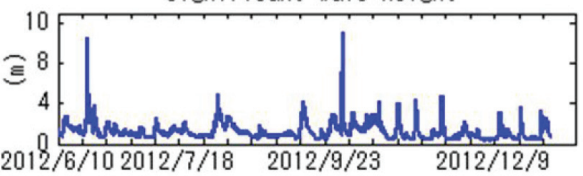

Significant Wave Period
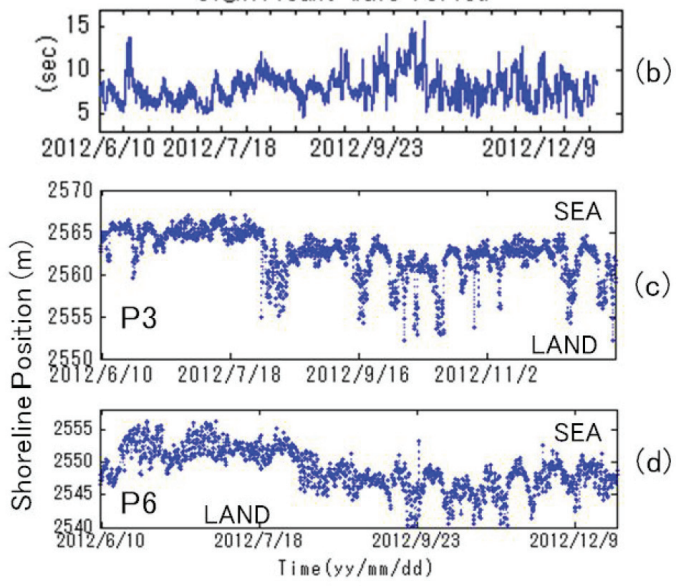

図-9＼cjkstart汀線変化と波浪の関係

Signif icant Wave Height

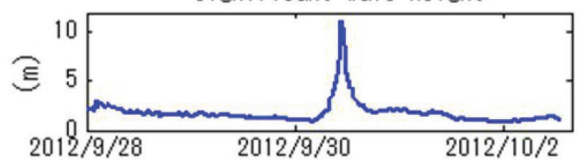

(a)

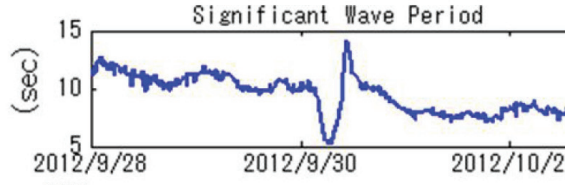

(b)

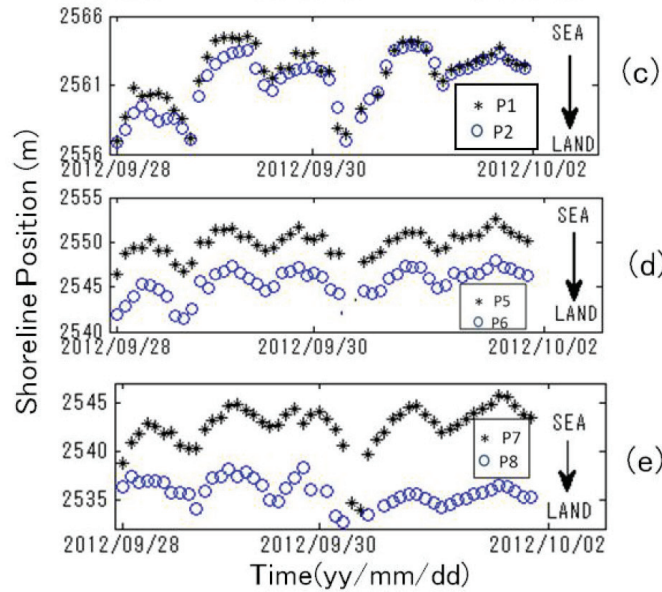

図-10 台風における汀線変化

間の汀線は，一度後退した後，回復の傾向が認められる. 一方，後半は $3 \mathrm{~m} \sim 4 \mathrm{~m}$ の波が間欠的に来襲するため，頻 繁に汀線が後退する傾向が確認できる.11月から 12 月の 


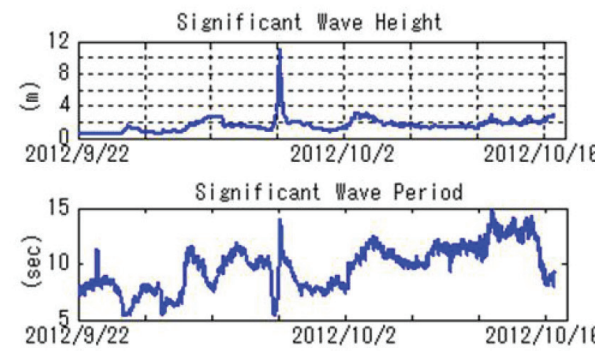

(a)

(b)

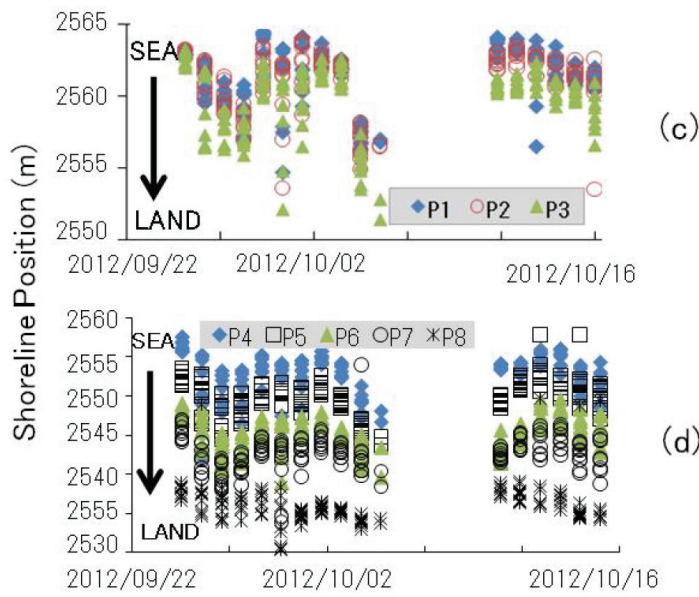

図-11 台風前後の汀線位置

期間は， $3 \mathrm{~m}$ 以上の波も入射しているが，頻度は低く，汀 線も一時的に後退するもののその後回復する傾向が認め られる。

\section{b）台風時の汀線変化}

前述のように，高波浪時に汀線が後退する傾向が確認 されたが，その主な気象要因である台風時の汀線につい て検討する。ここでは, 平成 24 年の 17 号を取り上げ, 台風の経過にともなう汀線変化を検討した. 17 号台風は, 平成 24 年 9 月 28 日から 10 月 1 日にかけて, 日本全国に影 響を及ぼしており，9月29日に沖縄本島付近を通過した 後，30日19時頃に愛知県東部に上陸した。気象庁による と三重県熊野市遊木町では9月30日17時6分頃の潮位が $134 \mathrm{~cm}$ となり, 三重県の沿岸で高潮が発生し, 最高潮位 を更新している，図-10に示すように，最大 $11 \mathrm{~m}$ の波高 が来襲した後, 汀線は約 $8 \mathrm{~m}$ 後退した。図-11は, 台風 17 号を含む前後約 1 ケ月の波浪と汀線変化を示したもので ある．図-11では，台風のピークが過ぎて波高が小さく なると汀線は回復傾向になるが, その後, 波高が $2 \mathrm{~m}$ を 超える期間があることから，台風の通過後，約 2 週間経 過した 10 月 18 日でも汀線は台風前の位置までは回復し ていない.

c) 汀線変化と人エリーフ

図-10（d）や図-10（e）からわかるように台風の場合
でも，人工リーフ背後のP5，P6，P7，P8では汀線の 後退量は人工リーフの設置されていない海浜よりも小 さいことが確認される。これは他の台風の場合でも確 認されている。 また, 台風の通過後の人工リーフ背後 の汀線の回復も人エリーフが設置されていない場所に 比べて早い傾向が確認された。したがって, 従来から いわれているように，人工リーフによる汀線後退への 有効性が確認される.

\section{4. おわりに}

本研究では七里御浜井田地区海岸に設置したWebカメ ラで撮影した画像にもとづき, 汀線変化を波浪と関連づ けて検討した．主な結論は以下にまとめる.

1）本研究で提案した方法により従来の CCD 法と比較し て安定して汀線を検出可能となった。

2) 七里御浜では波高が $1 \mathrm{~m}$ 前後では汀線は停滞傾向, 波 高が $1 \sim 2 \mathrm{~m}$ で前進傾向，波高が $3 \sim 4 \mathrm{~m}$ を超えると侵食 傾向となることが確認できた.

3）人工リーフが存在することで汀線の後退は緩やかに なる傾向があることが確認された。

今後, 潮位変化の補正などについても更に検討を加え, より詳細に検討を加えていく所存である.

謝辞：本研究を行うにあたり, 国土交通省関東地方整備 局横浜港湾空港技術調查事務所・鈴木高二朗氏（前独立 行政法人港湾空港技術研究所）に画像解析に上る汀線変 化の解析手法の構築に多大な協力を賜った。ここに記し て感謝の意を表します。また，同中部地方整備局紀勢国 道事務所, 三重県にはWebカメラの設置, および光ケー ブルの利用, 波浪デー夕の提供等で協力を賜った。関倸 各位に感謝申し上げます。最後に, 本研究は科学研究費 補助金基盤研究（B）（代表者：水谷法美）により行われ たことを付記し，関係各位に感謝の意を表します。

\section{参 考 文 献}

宇多高明・後藤康長 - 山本 幸 (1992) : 三重県七里御浜海岸 の海浜変形機構に関する一考察, 海工論文集，Vol. 39, pp. 351-355.

山本幸次，佐藤㯖司，野口賢二，宮野正実（1999）：熊野川を 土砂供給源とする海岸の海浜変形と砂磉層厚, 海岸工学 論文集，第46巻，Vol. 46, pp. 666-670.

水谷法美 - 許 東秀・上運天陽次 - 神谷篤史 (2003)：人工リ ーフと盖浜による磉浜海岸の汀線変化の現地調查とその 予測, 海岸工学論文集, Vol. 50, pp. 581-585.

鈴木高二朗・有路隆一・諸星一信・柳島慎一・高橋重雄・松 坂省一・鈴木信昭（2008）：WEBカメラを用いた海岸の 連続観測手法の開発について, 海岸工学論文集, Vol. 55, pp. 1446-1450.

李 光浩 - 藤井俊明 - 水谷法美 (2009)：砂浜斜面上の砕波特 性に関する実験的研究, 海洋開発論文集, Vol. 25, pp. 831-835. 